\title{
Growth, biomass production and ions accumulation in Atriplex nummularia Lindl grown under abiotic stress
}

\author{
Hidelblandi F. de Melo ${ }^{1}$, Edivan R. de Souza ${ }^{1}$, Brivaldo G. de Almeida ${ }^{1}$, \\ Maria B. G. dos S. Freire ${ }^{1}$ \& Fabíola E. Maia ${ }^{2}$ \\ ${ }^{1}$ Universidade Federal Rural de Pernambuco/Departamento de Agronomia/Programa de Pós-Graduação em Ciência do Solo. Recife, PE. E-mail: \\ hidelfarias@gmail.com; edivan.rodrigues@ufrpe.br (Corresponding author); brivaldoalmeida@gmail.com; maria.freire@ufrpe.br \\ ${ }^{2}$ Universidade Federal Rural de Pernambuco/Departamento de Engenharia Agrícola. Recife, PE. E-mail: fab20estrelamaia@gmail.com
}

Key words:

salt extraction

nutritional status

halophytes

Brazilian semiarid

\begin{abstract}
A B S T R A C T
Atriplex nummularia is a halophyte of great importance in the recovery of saline soils and is considered as a model plant to study biosaline scenarios. This study aimed to evaluate biometric parameters, biomass production and the accumulation of ions in A. nummularia grown under abiotic stresses. Cultivation was carried out in a Fluvic Neosol for 100 days, adopting two water regimes: 37 and 70\% of field capacity. Plants were irrigated with saline solutions containing two types of salts ( $\mathrm{NaCl}$ and a mixture of $\mathrm{NaCl}, \mathrm{KCl}, \mathrm{MgCl}_{2}$ and $\mathrm{CaCl}_{2}$ )

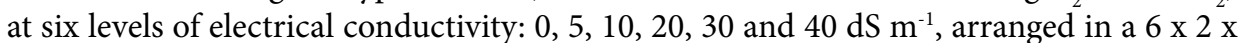
2 factorial with 4 replicates, forming 96 plots. At the end of the experiment, plants were divided into leaves, stem and roots, for the determination of fresh matter (FM), dry matter (DM) and estimated leaf area (LA), besides the contents of $\mathrm{Ca}^{2+}, \mathrm{Mg}^{2+}, \mathrm{Na}^{+}, \mathrm{K}^{+}$and $\mathrm{Cl}^{-}$. The type of salt did not influence plant growth or biomass production; however, it influenced the levels of $\mathrm{Ca}^{2+}, \mathrm{Mg}^{2+}, \mathrm{Na}^{+}$and $\mathrm{Cl}^{-}$in the leaves and $\mathrm{Mg}^{2+}, \mathrm{K}^{+}$and $\mathrm{Cl}^{-}$in the roots. Increase in salinity reduced the contents of $\mathrm{Ca}^{2+}, \mathrm{Mg}^{2+}, \mathrm{Na}^{+}, \mathrm{K}^{+}$and $\mathrm{Cl}^{-}$for all treatments.
\end{abstract}

\section{Palavras-chave:}

extração de sais

estado nutricional

halófitas

semiárido Brasileiro

\section{Crescimento, produção de biomassa e acumulação de íons em Atriplex cultivada sob estresses abióticos}

\begin{abstract}
R E S U M O
A Atriplex nummularia é uma halófita de grande importância na recuperação de solos salinos razão por que é bastante utilizada como planta modelo em condições biossalinas. O objetivo deste estudo foi avaliar parâmetros biométricos, produção de biomassa e a acumulação de íons em A. nummularia cultivada sob estresses hídrico e salino. Realizouse o cultivo em Neossolo Flúvico durante 100 dias sob duas condições de umidade do solo: 37 e $70 \%$ da capacidade de campo. As plantas foram irrigadas com soluções salinas obtidas a partir de dois tipos de sais ( $\mathrm{NaCl}$ e uma mistura de $\mathrm{NaCl}, \mathrm{KCl}, \mathrm{MgCl}_{2}$ e $\mathrm{CaCl}_{2}$ ) preparadas em seis condutividades elétricas: $0 ; 5 ; 10 ; 20 ; 30$ e $40 \mathrm{dS} \mathrm{m}^{-1}$ e dispostas em arranjo fatorial $6 \times 2 \times 2$ com 4 repetições, totalizando 96 parcelas. Por ocasião da colheita as plantas foram fracionadas em folhas, caule e raiz e determinadas a massa fresca (MF), a massa seca (MS) e a área foliar (AF); foram determinados os teores de $\mathrm{Ca}^{2+}, \mathrm{Mg}^{2+}, \mathrm{Na}^{+}, \mathrm{K}^{+}$ e $\mathrm{Cl}^{-}$. O tipo de sal não influenciou o crescimento nem a produção de biomassa; contudo, influenciou nos teores de $\mathrm{Ca}^{2+}, \mathrm{Mg}^{2+}, \mathrm{Na}^{+}$e $\mathrm{Cl}^{-}$nas folhas e nos teores de $\mathrm{Mg}^{2+}, \mathrm{K}^{+}$e $\mathrm{Cl}^{-} \mathrm{da}$ raiz. $\mathrm{O}$ aumento da condutividade elétrica reduziu o conteúdo de $\mathrm{Ca}^{2+}, \mathrm{Mg}^{2+}, \mathrm{Na}^{+}, \mathrm{K}^{+}$e $\mathrm{Cl}^{-}$em todos os tratamentos.
\end{abstract}




\section{INTRODUCTION}

Plants belonging to the Chenopodiaceae family are well adapted to saline and water stress (Glenn et al., 2012; Nedjimi, 2014; Souza et al., 2014) and can serve as an alternative for the production of palatable biomass in arid regions, where the environmental conditions are unfavorable for most crops (Silveira et al., 2009). Thus, plants in the Atriplex genus have become the target of many studies involving tolerance to salinity and drought (Nedjimi, 2014; Walker et al., 2014).

Atriplex nummularia, for instance, can be cultivated in arid regions with mean annual rainfall from 200 to 400 $\mathrm{mm}$. In addition, this halophyte has high capacity to explore groundwater and can reach up to $10 \mathrm{~m}$ below the surface (Norman et al., 2010).

In the field, the production of palatable dry matter of A. nummularia can range from $0.5 \mathrm{t} \mathrm{ha}^{-1}$ year-1 $^{-1}$ in salinized areas to $12 \mathrm{t} \mathrm{ha}^{-1}$ year-1 $^{-1}$ when irrigated, and the crop can reach productions of about 15-20 tha- year $^{-1}$ (Ben Salem et al., 2010). Soil texture, water availability and salinity are among the factors that can influence crop production (Barrett-Lennard, 2003; Ben Salem et al., 2010).

Atriplex nummularia is considered as a salt accumulator (Souza et al., 2011). The main ions accumulated by plants in the Atriplex genus are chloride and sodium (Flowers \& Colmer, 2008) and some species accumulate these ions in specialized compartments, such as trichomes and microvesicles. Its high value as a palatable source of minerals, antioxidants and proteins, besides the high contents of $\mathrm{S}, \mathrm{Mg}, \mathrm{Ca}$ and $\mathrm{P}$ in the leaves, justifies its indication for the diet of ruminants (Ben Salem et al., 2010).

Studies involving controlled salinity conditions, such as those conducted by Khedr et al. (2011), Bouchenak et al. (2012), Glenn et al. (2012) and Nedjimi (2014), have used $\mathrm{NaCl}$ in the elaboration of the saline treatments, promoting conditions different from those found by plants in the field. It is essential to conduct researches involving saline stress with solutions elaborated from other types of salts and ionic species that simulate the actual conditions found by plants in the irrigation water or in the soil solution (Matinzadeh et al., 2013; Belkheiri \& Mulas, 2013; Walker et al., 2014).

This study aimed to evaluate development, biomass production and accumulation of ions $\left(\mathrm{Ca}^{2+}, \mathrm{Mg}^{2+}, \mathrm{Na}^{+}, \mathrm{K}^{+}\right.$and $\mathrm{Cl}^{-}$) in A. nummularia plants cultivated under conditions of water stress (soil water content at 37 and $70 \%$ of field capacity) and saline stress, using solutions containing sodium chloride and a mixture of salts, including calcium, magnesium, sodium and potassium.

\section{Material ANd Methods}

The soil used in the experiment was collected in the rural area of the municipality of Pesqueira-PE, Brazil, specifically in the 'Nossa Senhora do Rosário' settlement, at the geographic coordinates of $8^{\circ} 34^{\prime} 11^{\prime \prime} \mathrm{S}$ and $37^{\circ} 48^{\prime} 54^{\prime \prime} \mathrm{W}$, in the layer of $0-30 \mathrm{~cm}$ and classified as non-saline, non-sodic Fluvic Neosol (EMBRAPA, 2013). The soil was air-dried, pounded to break up clods, homogenized and sieved through a $4-\mathrm{mm}$ grid, preserving its microaggregates.

For soil chemical characterization (Table 1), the following parameters were determined in air-dried fine earth (ADFE): $\mathrm{pH}_{\mathrm{H} 20}$ in the proportion of 1:2.5 (soil:water) and the exchangeable cations $\mathrm{Ca}^{2+}, \mathrm{Mg}^{2+}, \mathrm{Na}^{+}$and $\mathrm{K}^{+}$, extracted using $1 \mathrm{M}$ ammonium acetate (Thomas, 1982). The saturation extract was obtained through the preparation of the saturation paste (Richards, 1954), measuring its electrical conductivity (EC) and $\mathrm{pH}$. Cation exchange capacity (T) was determined using the index cation method (Richards, 1954). Based on the results obtained in the exchange complex, the values of sum of bases (SB) and the Exchangeable Sodium Percentage (ESP) were calculated.

For physical characterization (Table 2), the ADFE was analyzed for granulometry and clay dispersed in water through the hydrometer method, calculating the degree of clay dispersion and flocculation. Soil bulk density was determined using the graduated cylinder method and soil particle density, the volumetric flask method (EMBRAPA, 1997). Field capacity and permanent wilting point were determined based on the soil-water retention curve (SWRC). Total porosity was estimated using the values of soil bulk and particle density.

The experiment was carried out in a greenhouse for a period of 100 days, using $A$. nummularia plants cultivated in pots with capacity for $10 \mathrm{~kg}$ of soil, with one plant per pot.

After transplantation, plants were subjected to two gravimetric water contents in the soil: $0.17 \mathrm{~g} \mathrm{~g}^{-1}(-0.06 \mathrm{MPa})$ equivalent to $70 \%$ of field capacity, and $0.09 \mathrm{~g} \mathrm{~g}^{-1}(-0.52 \mathrm{MPa})$ equivalent to $37 \%$ of field capacity. These water contents were selected based on the soil-water retention curve (SWRC).

In order to guarantee genetic uniformity, clones of a single plant, produced from stem cuttings, were used in the

Table 1. Initial chemical characteristics of the Fluvic Neosol used to fill the pots in the greenhouse experiment

\begin{tabular}{ccc}
\hline \multicolumn{1}{c}{ Variables } & Values \\
& Saturation extract & \\
$\mathrm{pH}_{\mathrm{se}}$ & & 8.17 \\
$\left.\mathrm{EC}(\mathrm{dS} \mathrm{m})^{-1}\right)$ & 1.17 \\
\hline & Exchange complex \\
\hline $\mathrm{pH}_{(1: 2.5)}$ & 7.70 \\
$\mathrm{Ca}^{2+}\left(\mathrm{cmol}_{\mathrm{c}} \mathrm{kg}^{-1}\right)$ & 5.53 \\
$\mathrm{Mg}^{2+}\left(\mathrm{cmol}_{\mathrm{c}} \mathrm{kg}^{-1}\right)$ & 2.22 \\
$\mathrm{Na}^{+}\left(\mathrm{cmol}_{\mathrm{c}} \mathrm{kg}^{-1}\right)$ & 0.26 \\
$\mathrm{~K}^{+}\left(\mathrm{cmol}_{\mathrm{c}} \mathrm{kg}^{-1}\right)$ & 0.50 \\
$\mathrm{SB}\left(\mathrm{cmol}_{\mathrm{c}} \mathrm{kg}^{-1}\right)$ & 8.51 \\
$\mathrm{ESP}(\%)$ & 3.00 \\
\hline $\mathrm{pH} \cdot \mathrm{pH}-$ Determined in the saturation extract: ESP - Exchangeable sodium percentage:
\end{tabular}

$\mathrm{pH}_{\mathrm{s}}: \mathrm{pH}$ - Determined in the saturation extract; ESP - Exchangeable sodium percentage; $\mathrm{SB}$ - Sum of bases; EC - Electrical conductivity

Table 2. Initial physical characteristics of the Fluvic Neosols used to fill the pots in the greenhouse experiment

\begin{tabular}{|c|c|c|c|c|c|c|c|c|c|c|c|c|}
\hline & Sand & & cilt & Clov & CnW & $\mathrm{nc}_{c}$ & $\mathrm{n}_{n}$ & \multirow{3}{*}{ DF } & \multirow{3}{*}{ DCD } & \multirow{3}{*}{$\begin{array}{l}\text { TP } \\
\%\end{array}$} & FC & \multirow{3}{*}{ PWP } \\
\hline Fine & Coarse & Total & Silt & Glay & CDW & US & Up & & & & & \\
\hline \multicolumn{6}{|c|}{$\mathrm{g} \mathrm{kg}^{-1}$} & \multicolumn{2}{|c|}{$\mathrm{g} \mathrm{cm}^{-3}$} & & & & $\mathrm{~g} \mathrm{~g}^{-1}$ & \\
\hline 435 & 17 & 452 & 386 & 162 & 117 & 1.36 & 2.66 & 0.28 & 0.72 & 49.57 & 0.24 & 0.05 \\
\hline
\end{tabular}

CDW - Clay dispersed in water; Dp - Soil particle density; Ds - Soil bulk density; DCD - CDW/Clay; DF: (1 - DCD); DCD - Degree of clay dispersion; DF - degree of flocculation; TP - Total porosity 
experiment. The stem cuttings were transplanted to pots 90 days after propagation with standardized height of $19 \mathrm{~cm}$; during the cultivation, the seedlings were not subjected to any fertilization and were irrigated with only tap water.

Initially, plants were irrigated for 20 days with only distilled water and the electrical conductivity was gradually increased in order to avoid osmotic shock on the transplanted plants. During the experiment, the water content in the pots was maintained through daily weighings performed in the late afternoon, for the equilibrium of the desired water content, compensating the losses through evaporation.

The solutions used in the experiment were elaborated with two types of salts, one composed only of $\mathrm{NaCl}$ and the other composed of a mixture of salts with proportions similar to that of an artesian well, located close to the soil-sampling site. These solutions were prepared with six values of electrical conductivity: 0, 5, 10, 20, 30 and $40 \mathrm{dS} \mathrm{m}^{-1}$ (Silveira et al., 2009; Belkheiri \& Mulas, 2011).

Plant height was periodically measured for growth evaluation at 45, 65 and 85 days after transplantation (DAT). At 100 DAT, plants were cut close to the soil surface, divided into leaves and stems, weighed and the fresh matter was determined. Roots were collected through washing in running water until the complete removal of soil; then, they were dried in paper towel and the fresh matter was determined. For dry matter determination, leaves, stems and roots were placed in a forced-air oven at $65^{\circ} \mathrm{C}$ until constant weight.

Leaf area was estimated based on the leaf disc method (Souza et al., 2012b). Leaf discs with known area were collected using a leaf-disc sampler (Area $=1 \mathrm{~cm}^{2}$ ), placed in paper packages, dried in an oven $\left(65^{\circ} \mathrm{C}\right.$ for $\left.72 \mathrm{~h}\right)$ and weighed separately, per plant. Leaf area was estimated through Eq. 1:

$$
\mathrm{LA}=\frac{(\mathrm{DML}+\mathrm{DMD}) \times \mathrm{KAD}}{\mathrm{DMD}}
$$

where:

LA - estimated leaf area $\left(\mathrm{cm}^{2}\right)$;

DML - dry mass of leaves ( $\mathrm{g})$;

DMD - dry mass of discs (g); and

KAD - known area of the collected leaf disc, in this case $1.0 \mathrm{~cm}^{2}$.

Leaves, stems and roots were ground in a Wiley-type mill and the nitric-perchloric digestion was performed (Silva et al.,
2008). The contents of $\mathrm{Na}^{+}$and $\mathrm{K}^{+}$were determined through flame emission photometry and the contents of $\mathrm{Ca}^{2+}$ and $\mathrm{Mg}^{2+}$ through atomic absorption spectrophotometry. Chloride was determined through extraction in water and titration with $\mathrm{AgNO}_{3}$ (Malavolta et al., 1989).

The treatments were arranged in a randomized block design, with four replicates (blocks), in a 2 x 2 x 6 factorial, with two soil water contents ( 37 and $70 \%$ of field capacity), two saline solutions $\left(\mathrm{NaCl}\right.$ and a mixture of $\mathrm{NaCl}, \mathrm{KCl}, \mathrm{MgCl}_{2}$ and $\left.\mathrm{CaCl}_{2}\right)$ and six levels of electrical conductivity $(0,5,10,20,30$ and $40 \mathrm{dS} \mathrm{m}^{-1}$ ). The data were subjected to the assumptions of normality and analysis of variance. For quantitative variables, equations of regression models were adjusted and, for the variables that did not fit to the models, the mean and the standard deviation were used to present the data.

\section{Results AND Discussion}

For plant height, measured at 45, 65 and 85 days after transplantation, there was significant difference for the interaction Water content x Electrical conductivity (Figure 1). There was no significant effect on plant growth, according to the analysis of variance, with respect to the type of salt.

Plant height decreased with the increase in electrical conductivity for both water contents; at the highest EC level, plants at $70 \%$ FC were $20 \%$ shorter than plants in the control, while plants at $37 \%$ FC showed higher reduction (22\%), due to the water stress.

At 85 DAT, plants under EC of $5 \mathrm{dS} \mathrm{m}^{-1}$ showed mean increment of $62 \mathrm{~cm}$ at $70 \% \mathrm{FC}$, while plants at $37 \% \mathrm{FC}$ grew 31 $\mathrm{cm}$ in the same period (Figure 1C); in this case, the reduction of $50 \%$ in plant height can be attributed to the water stress.

The biomass production of leaves, stems and roots showed significant effects, according to the analysis of variance, for the interaction Water content $x$ Electrical conductivity (Table 3).

Leaf fresh and dry matters were the most affected variables in the plants (Table 3). Plants subjected to $70 \%$ FC and EC of $40 \mathrm{dS} \mathrm{m} \mathrm{m}^{-1}$, for instance, suffered reduction of $94 \%$ in leaf biomass, compared with the control. For plants under water stress ( $37 \%$ FC), this reduction was equal to $91 \%$, while for both water contents, the highest leaf biomass production was

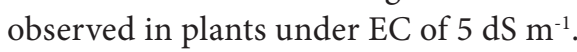

According to Flowers \& Colmer (2008), this reduction in dry biomass production in halophytes occurs when plants are
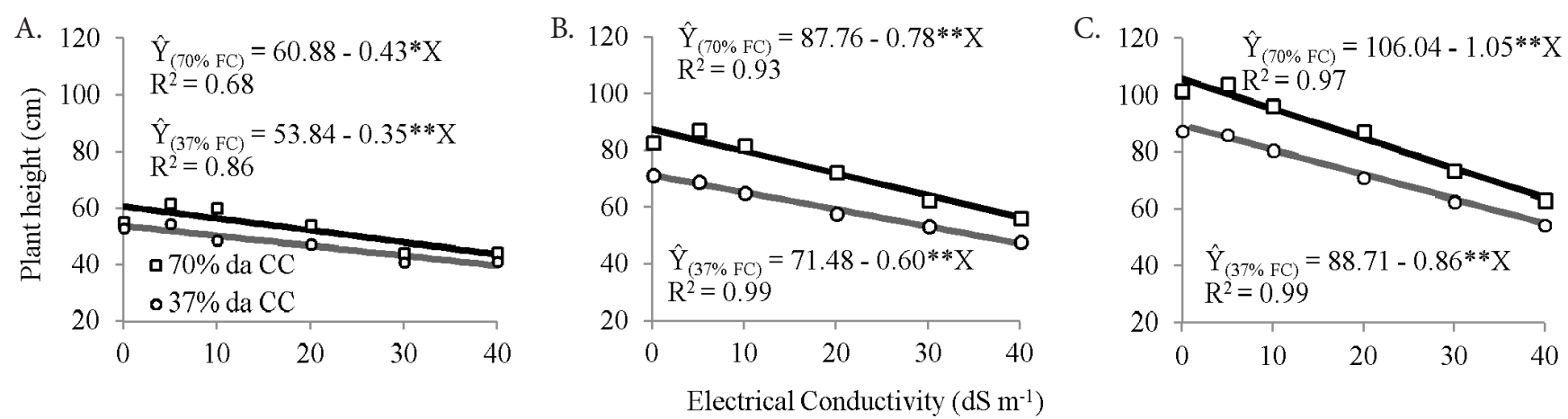

Figure 1. Atriplex nummularia plant height at 45 (A), 65 (B) and 85 (C) days after transplantation as a function of the electrical conductivity level of the irrigation water at the water contents of 70 and $37 \%$ of field capacity (FC) 
Table 3. Mean production $(n=4)$ of fresh and dry matter $(g)$ of leaves, stems and roots of Atriplex nummularia 100 days after transplantation as a function of the level of the electrical conductivity (EC) of the irrigation water, at the water contents of 70 and $37 \%$ of field capacity

\begin{tabular}{|c|c|c|c|c|c|c|c|c|c|c|c|c|}
\hline \multirow{4}{*}{$\begin{array}{c}E C \\
\left(\mathrm{dS} \mathrm{m}^{-1}\right)\end{array}$} & \multicolumn{6}{|c|}{ Fresh matter } & \multicolumn{6}{|c|}{ Dry matter } \\
\hline & \multicolumn{2}{|c|}{ Leaves } & \multicolumn{2}{|c|}{ Stems } & \multicolumn{2}{|c|}{ Roots } & \multicolumn{2}{|c|}{ Leaves } & \multicolumn{2}{|c|}{ Stems } & \multicolumn{2}{|c|}{ Roots } \\
\hline & 70 & 37 & 70 & 37 & 70 & 37 & 70 & 37 & 70 & 37 & 70 & 37 \\
\hline & \multicolumn{12}{|c|}{$\%$} \\
\hline 0 & 47.40 & 35.18 & 56.68 & 31.94 & 17.45 & 14.39 & 10.6 & 7.8 & 29.2 & 16.5 & 5.5 & 4.1 \\
\hline 5 & 58.07 & 38.16 & 56.22 & 29.69 & 18.51 & 18.12 & 12.3 & 7.9 & 30.3 & 15.0 & 6.3 & 4.8 \\
\hline 10 & 50.04 & 32.01 & 44.14 & 19.03 & 17.15 & 14.11 & 11.3 & 6.8 & 24.2 & 10.0 & 5.5 & 3.7 \\
\hline 20 & 25.17 & 9.82 & 19.43 & 8.43 & 12.89 & 6.38 & 6.4 & 2.6 & 10.7 & 4.7 & 3.5 & 2.1 \\
\hline 30 & 8.55 & 2.31 & 10.50 & 4.54 & 8.80 & 3.28 & 2.5 & 0.7 & 5.8 & 2.5 & 2.5 & 1.4 \\
\hline 40 & 3.27 & 3.15 & 8.22 & 5.01 & 7.99 & 4.68 & 1.1 & 0.9 & 4.4 & 2.9 & 2.3 & 1.6 \\
\hline
\end{tabular}

exposed to very high levels of salinity, $250 \mathrm{mmol}$ of $\mathrm{NaCl}$. In a study conducted by Hassine \& Lutts (2010), the concentration of $160 \mathrm{mmol}$ of $\mathrm{NaCl}$ stimulated the increase in dry biomass production in the shoots of Atriplex halimus, while the water stress of -0.64 MPa reduced it to half, compared with the control treatment and the saline stress.

Plants under water stress showed lower biomass production for all the EC levels (Table 3). Water stress was the most limiting factor for leaf and stem production at all the EC levels below $30 \mathrm{dS} \mathrm{m}^{-1}$; however, for values equal to or higher than $30 \mathrm{dS} \mathrm{m}^{-1}$, salinity became the greatest limitation (Table 3 ).

For root fresh and dry biomass, water stress reduced the production for all the EC levels, except $5 \mathrm{dS} \mathrm{m}^{-1}$. However, the highest reductions occurred due to the saline stress. Belkheiri \& Mulas (2013) observed higher reduction in root biomass in plants under saline stress, in comparison to its combination with water stress. Saline stress seems to be the factor with the highest influence on root production (Silveira et al., 2009).

Leaf area showed significant effect only for the interaction Water content $\mathrm{x}$ Electrical conductivity. The type of salt did not cause significant difference (Figure 2).

Leaf area decreased with the increment in EC, except for the level of $5 \mathrm{dS} \mathrm{m} \mathrm{m}^{-1}$, which showed the highest leaf area compared

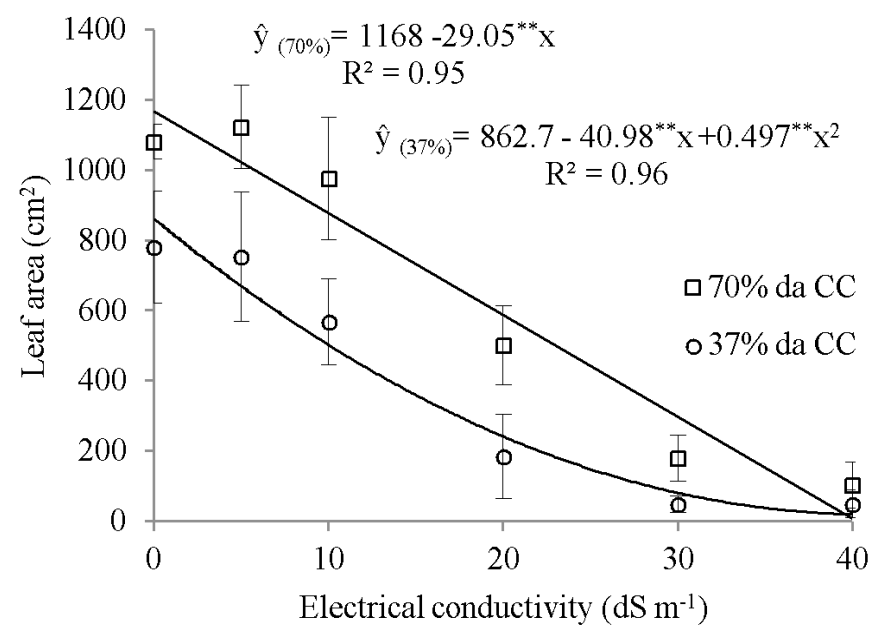

Vertical bars indicate the mean standard deviation

Figure 2. Atriplex nummularia leaf area as a function of the level of electrical conductivity of the irrigation water, 100 days after transplantation, at the water contents of 70 and $37 \%$ of field capacity with the control. The reduction in the photosynthetically active area due to salinity also leads to the reduction in carbon fixation (Flowers \& Colmer, 2008) and, consequently, in biomass production and plant height (Figures 1 and 3; Table 2). Belkheiri \& Mulas (2013) reported increase in leaf area of Atriplex nummularia irrigated with $\mathrm{NaCl}$ solution at the EC levels of $0,10,30,40,60$ and $80 \mathrm{dS} \mathrm{m} \mathrm{m}^{-1}$, after 10 days of treatment; however, at 20 days, all the plants under EC higher than $30 \mathrm{dS} \mathrm{m}^{-1}$ reduced their leaf area compared with the others. Even halophytes, such as A. nummularia, can suffer deleterious effects due to the intensity of the stress and the exposure time (Kachout et al., 2009).

The leaf contents of $\mathrm{Ca}^{2+}, \mathrm{Mg}^{2+}, \mathrm{Na}^{+}$and $\mathrm{Cl}^{-}$showed significant difference for the interaction Water content $\mathrm{x}$ Electrical conductivity; the type of salt also caused significant difference (Figure 3).

The elements with higher accumulation in the leaves of Atriplex nummularia were chloride and sodium, respectively. Chloride contents increased with the increment in EC at both water contents and for both type of salt (Figures 3A, B, C and D). Higher chloride contents in response to the increase of EC in A. nummularia plants have been reported in other studies, such as Souza et al. (2012a) and Nedjimi (2014).

Increase in $\mathrm{Na}$ contents until the $\mathrm{EC}$ of $30 \mathrm{dS} \mathrm{m}^{-1}$ were observed in the leaves, for the treatments with $\mathrm{NaCl}$ (Figure $3 \mathrm{~A}$ and B). Hussin et al. (2013) observed similar behavior within the same EC range $\left(\sim 0,2.5,5,10\right.$ and $\left.15 \mathrm{dS} \mathrm{m}^{-1}\right)$ after 84 days of treatment. Plants subjected to EC higher than 30 $\mathrm{dS} \mathrm{m} \mathrm{m}^{-1}$ reduced $\mathrm{Na}^{+}$contents with the increase in electrical conductivity.

In the evaluation of the phytoextraction potential of $A$. nummularia with respect to $\mathrm{Na}^{+}$, Souza et al. (2012a) observed $124.73 \mathrm{~g} \mathrm{~kg}^{-1}$ of $\mathrm{Na}^{+}$in the leaves of plants cultivated for 134 days in saline, sodic soil. Bazihizina et al. (2012) observed $45.9 \mathrm{~g} \mathrm{~kg}^{-1}$ of $\mathrm{Na}^{+}$in the leaves of $A$. nummularia under saline stress of $1500 \mathrm{mmol}\left(150 \mathrm{dS} \mathrm{m}^{-1}\right)$ of $\mathrm{NaCl}$ after 21 days. In the present study, the highest $\mathrm{Na}^{+}$content $\left(131 \mathrm{~g} \mathrm{~kg}^{-1}\right)$ was observed in plants under $70 \% \mathrm{FC}$ and EC of $30 \mathrm{dS} \mathrm{m}^{-1}$. This value is consistent with previous studies and corroborates the accumulation of this element in the leaves of this species (Souza et al., 2012a; Bazihizina et al., 2012).

The contents of $\mathrm{Ca}^{2+}, \mathrm{Na}^{+}, \mathrm{K}^{+}$and $\mathrm{Cl}^{-}$in the stem of Atriplex nummularia were significant for the interaction Water content $\mathrm{x}$ Electrical conductivity, but not significant for the type of salt (Figure 4). 

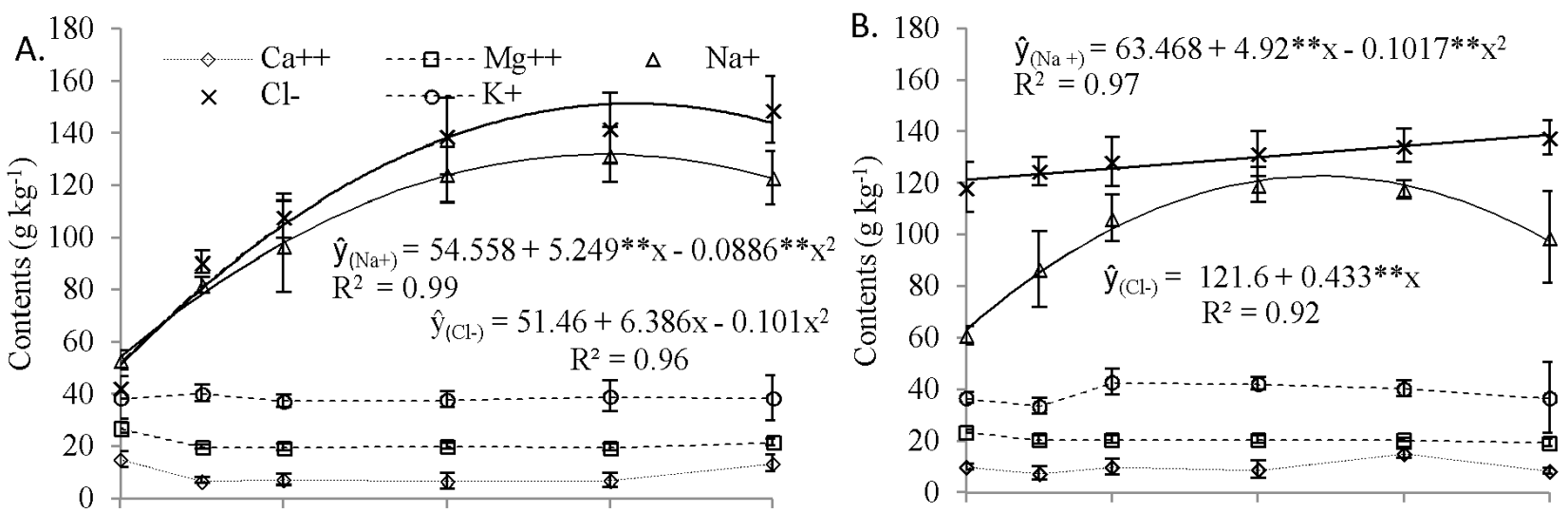

C.

D.
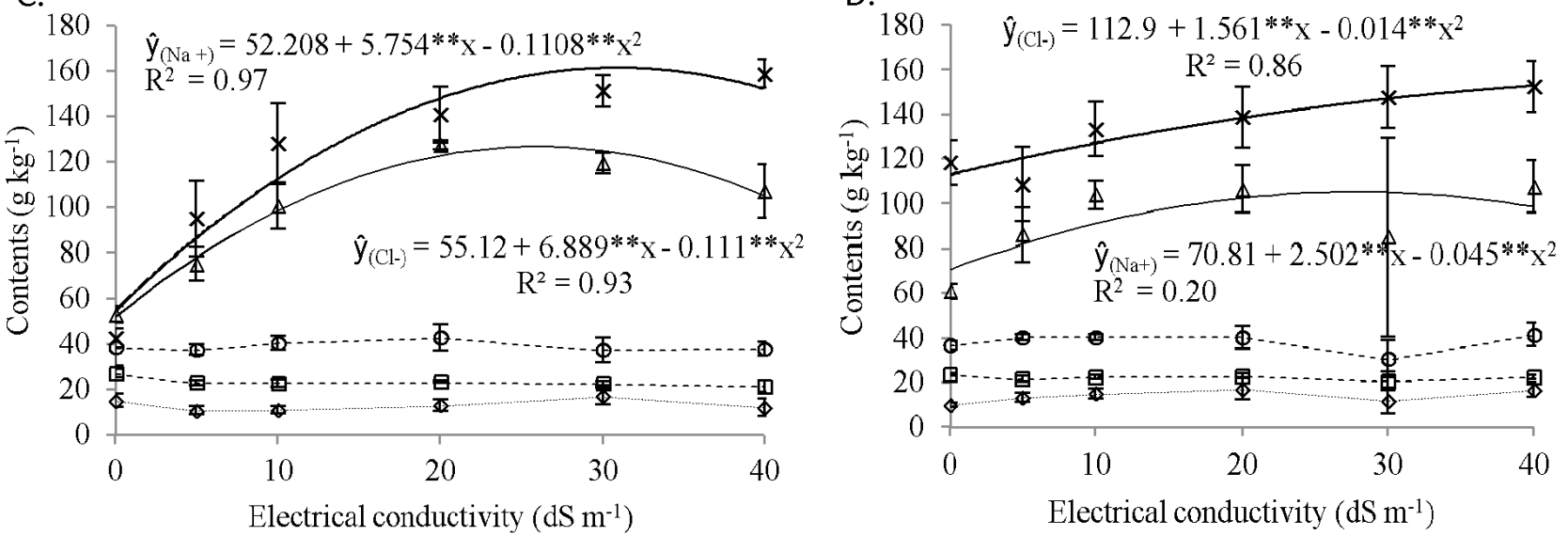

Vertical bars indicate the mean standard deviation

Figure 3. Contents of calcium, magnesium, potassum, sodium and chloride in the leaves of Atriplex nummularia irrigated with $\mathrm{NaCl}(\mathrm{A}$ and $\mathrm{B})$ and a mixture of salts $(\mathrm{C}$ and $\mathrm{D})$ at 70 and $37 \%$ of the field capacity, at 100 days after transplantation
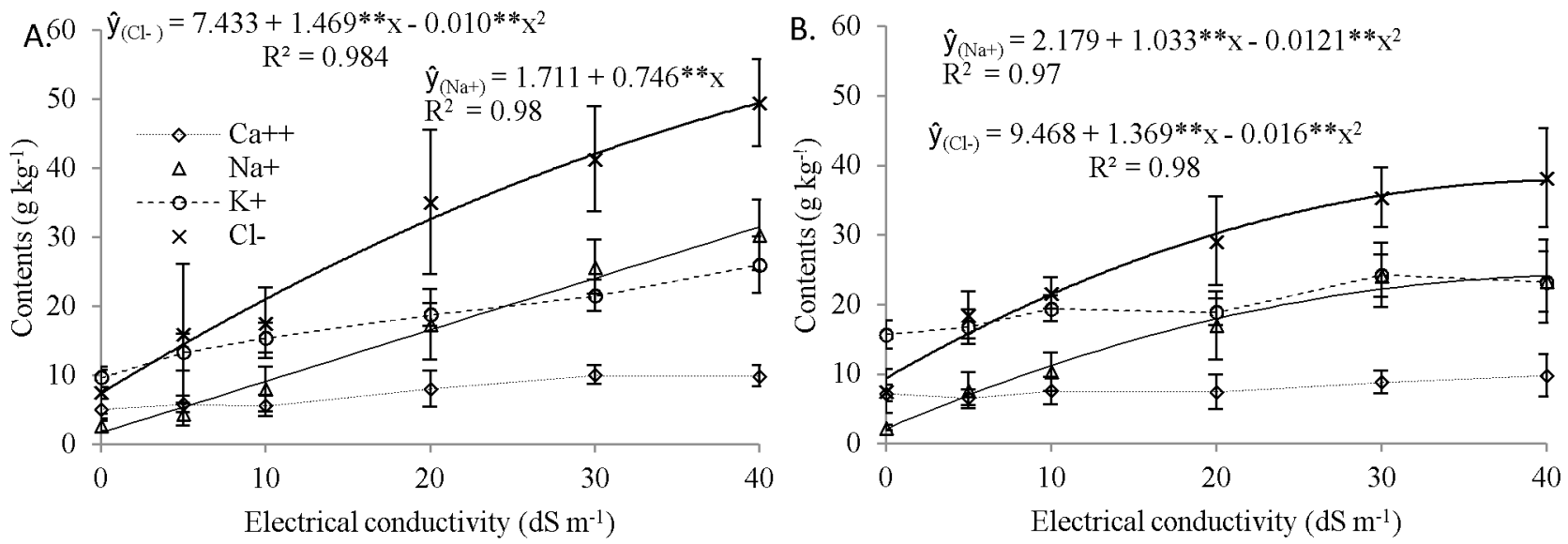

Vertical bars indicate the mean standard deviation

Figure 4. Contents of calcium, potassium, sodium and chloride in the stem of Atriplex nummularia for the water contents of $70 \%(\mathrm{~A})$ and $37 \%(\mathrm{~B})$ of field capacity, at 100 days a fter transplantation

In the stem, the contents of chloride, sodium and potassium were higher with the increase in EC. Chloride was the element found in highest amounts, followed by potassium and sodium. Plants subjected to 70\% FC showed higher sodium contents for the last two levels of EC, in comparison to those under water stress. Water stress reduced the contents of all the elements in plant stems, except for calcium, which was higher for the first EC levels.

For the contents of sodium, leaves and stems showed significant effect for the interaction Water content $x$ Electrical conductivity; there was significant effect of type of salt on leaves and roots (Figure 5).
While in the stems, $\mathrm{Na}^{+}$contents in plants under $37 \%$ FC decreased for the EC levels of 30 and $40 \mathrm{dS} \mathrm{m}^{-1}$ (Figure $5 \mathrm{D})$, the same reduction in $\mathrm{Na}^{+}$content was observed in the roots, between the type of salt, decreasing for the mixture. Although it showed a behavior similar to that of the EC from 0 to $20 \mathrm{dS} \mathrm{m}^{-1}$, for the EC levels of 30 and $40 \mathrm{dS} \mathrm{m}^{-1}$, the values were different, with higher contents in plants irrigated with $\mathrm{NaCl}$, which showed a response similar to that reported by Nedjimi (2014), who observed increasing contents as a function of the increment in electrical conductivity. 

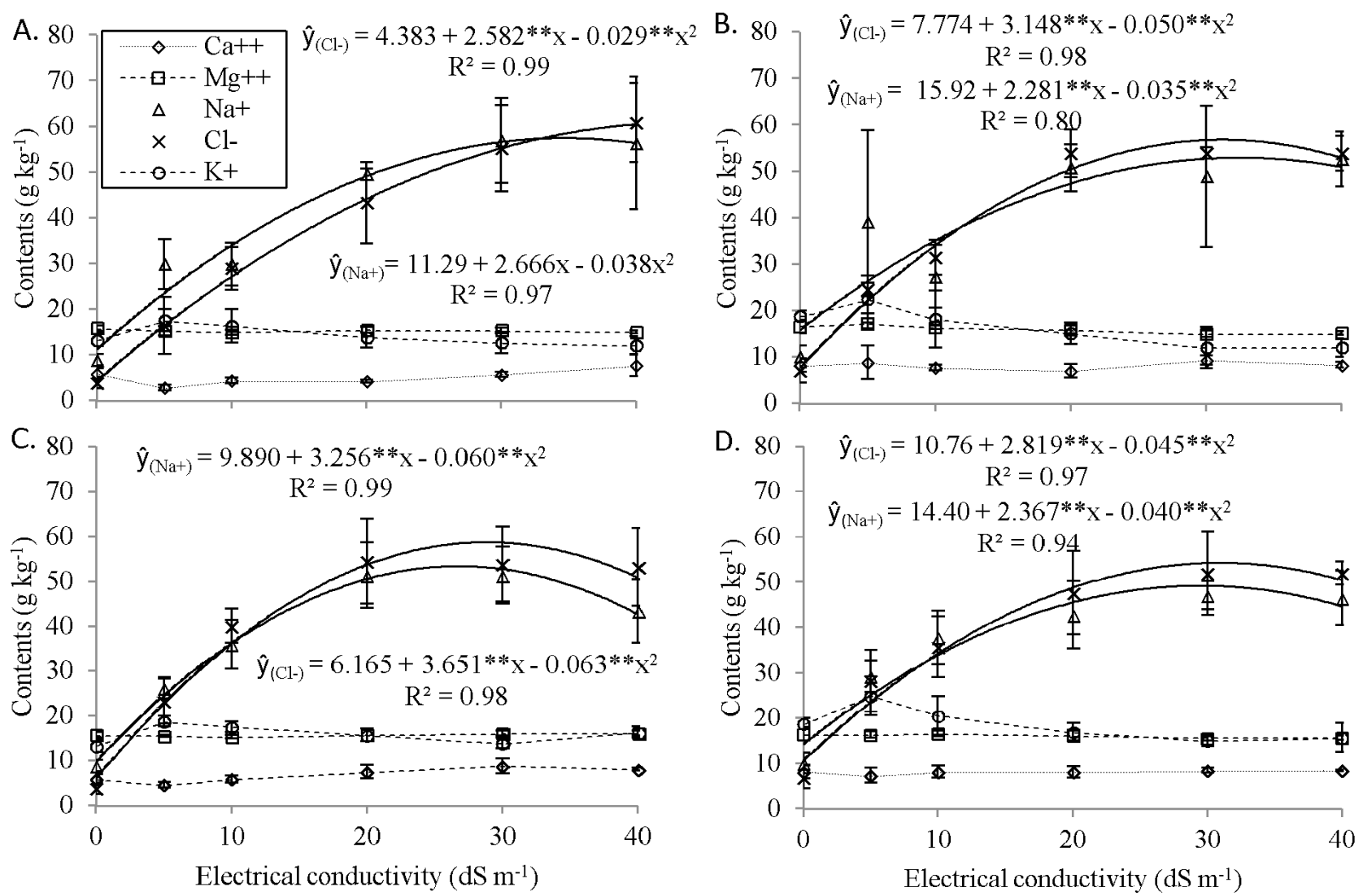

Vertical bars indicate the mean standard deviation

Figure 5. Contents of calcium, magnesium, potassium, sodium and chloride in roots of Atriplex nummularia irrigated with $\mathrm{NaCl}(\mathrm{A}$ and $\mathrm{B})$ and a mixture of salts $(\mathrm{C}$ and $\mathrm{D})$ at 70 and $37 \%$ of field capacity at 100 days after transplantation

Table 4. Contents $\left(\mathrm{g}\right.$ plant ${ }^{-1}$ ) of $\mathrm{Ca}^{2+}, \mathrm{Mg}^{2+}, \mathrm{Na}^{+}, \mathrm{K}^{+}$and $\mathrm{Cl}^{-}$in Atriplex nummularia plants 100 days after transplantation

\begin{tabular}{|c|c|c|c|c|c|c|c|c|c|c|c|}
\hline \multirow{2}{*}{$\begin{array}{l}\text { FC } \\
(\%)\end{array}$} & \multirow{2}{*}{$\begin{array}{c}E C \\
\left(\mathrm{dS} \mathrm{m}^{-1}\right)\end{array}$} & \multicolumn{5}{|c|}{$\mathrm{NaCl}$} & \multicolumn{5}{|c|}{ Mixture } \\
\hline & & $\mathrm{Ca}^{2+}$ & $\mathrm{Mg}^{2+}$ & $\mathrm{Na}^{+}$ & $\mathrm{K}^{+}$ & $\mathrm{Cl}^{-}$ & $\mathrm{Ca}^{2+}$ & $\mathrm{Mg}^{2+}$ & $\mathrm{Na}^{+}$ & $\mathrm{K}^{+}$ & $\mathrm{Cl}^{-}$ \\
\hline \multirow{6}{*}{70} & 0 & $0.34 \pm 0.07$ & $0.89 \pm 0.20$ & $0.69 \pm 0.06$ & $0.74 \pm 0.13$ & $0.77 \pm 0.11$ & $0.34 \pm 0.07$ & $0.89 \pm 0.20$ & $0.69 \pm 0.06$ & $0.74 \pm 0.13$ & $0.77 \pm 0.1$ \\
\hline & 5 & $28 \pm 0.03$ & $.95 \pm 0.12$ & $1.27 \pm 0$ & $03 \pm$ & $1.80 \pm$ & 17 & $0.93 \pm 0$ & $1.27 \pm$ & $.08 \pm$ & \\
\hline & 10 & $26 \pm c$ & $78 \pm 0$ & $1.47 \pm 0$ & $0.96 \pm$ & $1.82 \pm$ & $28 \pm$ & $0.74 \pm$ & $1.49 \pm$ & $1.03 \pm$ & $2.02 \pm$ \\
\hline & 20 & $4 \pm 1$ & $35 \pm$ & $1.18 \pm 0$ & $4 \pm$ & $1.45 \pm$ & $19 \pm$ & $0.36 \pm$ & $1.14 \pm$ & $0.63 \pm$ & $1.33 \pm$ \\
\hline & 30 & $9 \pm$ & $19 \pm 0$ & $0.67 \pm 0.31$ & $0.39 \pm$ & $0.78 \pm 0$ & $11 \pm$ & $0.18 \pm$ & $0.52 \pm 0.60$ & $0.32 \pm$ & $0.69 \pm$ \\
\hline & 40 & \pm & $13 \pm 0.10$ & $0.40 \pm 0.20$ & $6 \pm$ & $0.43 \pm 0$ & $07 \pm$ & $0.13 \pm$ & $0.34 \pm$ & $0.27 \pm$ & $0.51 \pm 0.21$ \\
\hline \multirow{6}{*}{3} & 0 & $3 \pm$ & $56 \pm$ & $0.56 \pm 0$ & $0 \pm$ & $0.69 \pm$ & $0.23 \pm$ & $0.56 \pm$ & $0.56 \pm$ & $0.60=$ & $0.69 \pm$ \\
\hline & 5 & & 08 & 1.01 & \pm & $1.29 \pm$ & $22 \pm$ & & $0.87 \pm$ & $0.68 \pm$ & $1.20 \pm($ \\
\hline & 10 & $9 \pm 0$ & $0.43 \pm 0.03$ & $1.03 \pm 0.04$ & $0.65 \pm 0$ & $1.27 \pm 0$ & $0.18 \pm 0$ & $0.33 \pm 0.25$ & $0.84 \pm 0.42$ & $0.55 \pm 0.29$ & $1.07 \pm 0.56$ \\
\hline & 20 & & $15 \pm 0.03$ & $0.47 \pm 012$ & $29 \pm 0$ & $0.53 \pm 0$ & $.09 \pm 0$ & $0.16 \pm 0.23$ & $0.46 \pm 0.52$ & $0.30 \pm 0.32$ & $0.57 \pm 0.65$ \\
\hline & 30 & & $08 \pm 0.14$ & $0.21 \pm 0.10$ & $5 \pm 0$ & $0.27 \pm 0$ & $5 \pm 0.02$ & $0.07 \pm 0$ & $0.20 \pm 0.18$ & $0.16 \pm 0.11$ & $0.27 \pm 0.23$ \\
\hline & 40 & $0.04 \pm 0.05$ & $0.08 \pm 0.19$ & $0.25 \pm 0.07$ & $0.19 \pm 0.14$ & $0.38 \pm 0.38$ & $0.06 \pm 0.18$ & $0.09 \pm 0.36$ & $0.24 \pm 0.64$ & $0.18 \pm 0.63$ & $0.25 \pm 0.94$ \\
\hline
\end{tabular}

FC - Field capacity

The contents of chloride and sodium in the roots showed similar behavior; in plants irrigated with $\mathrm{NaCl}$, the contents were slightly higher compared with plants irrigated with a mixture of salts. In addition, there was a stabilization of the values for the EC levels of 20, 30 and $40 \mathrm{dS} \mathrm{m}^{-1}$, regardless of the type of salt. This behavior was similar for both water regimes. Thus, despite being a halophyte, Atriplex nummularia has a limit for the accumulation of the ions chloride and sodium in the roots (Belkheiri\& Mulas, 2013).

In the study conducted by Silveira et al. (2009), roots of Atriplex nummularia under saline stress showed the highest contents of potassium compared with the other plant parts, decreasing with the increment in electrical conductivity. Bouchenack et al. (2012) observed similar behaviors between leaf and root contents. However, in the present study, leaf contents were higher than root contents.

Based on the values of dry matter and contents of the elements in the three plant parts, the contents of $\mathrm{Ca}^{2+}, \mathrm{Mg}^{2+}$, $\mathrm{Na}^{+}, \mathrm{K}^{+}$and $\mathrm{Cl}^{-}$were estimated, which reduced with the increment in electrical conductivity (Table 4 ). This reduction in the contents of these ions occurred as a response to the reduction of biomass production, which is characteristic of plants cultivated under very high electrical conductivity (Belkheiri \& Mulas, 2013).

\section{Conclusions}

1. The type of salt does not interfere with plant growth; however, water stress reduces plant height at all the levels of 
electrical conductivity and is more pronounced for the highest levels of electrical conductivity

2. The electrical conductivity of $5 \mathrm{dS} \mathrm{m}^{-1}$ stimulates the increase in biomass production, growth and leaf area, and is the level of best adaptability, even under water stress conditions.

3. The contents of calcium, magnesium, sodium and chloride in the leaves of Atriplex nummularia and the contents of magnesium, potassium and chloride in the roots are influenced by the type of salt in the environment.

4. The increase in electrical conductivity reduced the contents of $\mathrm{Ca}^{2+}, \mathrm{Mg}^{2+}, \mathrm{Na}^{+}, \mathrm{K}^{+}$and $\mathrm{Cl}^{-}$in all the treatments.

\section{ACKNOWLedgments}

The authors are grateful to Conselho Nacional de Desenvolvimento Científico e Tecnológico (CNPq) for the financial supported received (Edital Universal Number:473817/2013-6) and Pró-Reitoria de Pesquisa e Pós-Graduação of UFRPE (Edital 09/2014).

\section{Literature Cited}

Barrett-Lennard, E. G. The interaction between water logging and salinity in higher plants: Causes, consequences and implications. Plant Soil, v.253, p.35-54, 2003. http://dx.doi. org/10.1023/A:1024574622669

Bazihizina, N.; Barrett-Lennard, E. G.; Colmer, T. D. Plant responses to heterogeneous salinity: Growth of the halophyte Atriplex nummulariais determined by the root-weighted mean salinity of the root zone. Journal of Experimental Botany, v.63, p.6347-6358, 2012. http://dx.doi.org/10.1093/jxb/ers302

Belkheiri, O.; Mulas, M. The effects of salt stress on growth, water relations and ion accumulation in two halophyte Atriplex species. Environmental and Experimental Botany, v.86, p.112, 2011.

Belkheiri, O.; Mulas, M. Effect of water stress on growth, water use efficiency and gas exchange as related to osmotic adjustment of two halophytes Atriplex spp. Functional Plant Biology, v.40, p.466474, 2013. http://dx.doi.org/10.1071/FP12245

Ben Salem, H.; Norman, H. B. C.; Nefzaoui, A.; Mayberry, D. E.; Pearce, K. L.; Revellb, D. K. Potential use of oldman saltbush (Atriplex nummularia Lindl.) in sheep and goat feeding. Small Ruminant Research, v.91, p.13-28, 2010. http://dx.doi.org/10.1016/j. smallrumres.2009.10.017

Bouchenak, F.; Henri, P.; Benrebiha, F. Z.; Rey, P. Differential responses to salinity of two Atriplex halimus populations in relation to organic solutes and antioxidant systems involving thiolreductases. Journal of Plant Physiology, v.169, p.1445-1453, 2012. http:// dx.doi.org/10.1016/j.jplph.2012.06.009

EMBRAPA - Empresa Brasileira de Pesquisa Agropecuária. Manual de métodos de analise de solo. 1.ed. Rio de Janeiro: EMBRAPA, 1997. 212p.

EMBRAPA - Empresa Brasileira de Pesquisa Agropecuária. Sistema brasileiro de classificação de solos. 3.ed. Brasília, 2013. 353p.

Flowers, T. J.; Colmer, T. D. Salinity tolerance in halophytes. New Phytologist, v.179, p.945-963, 2008. http://dx.doi.org/10.1111/ j.1469-8137.2008.02531.x
Glenn, E. P.; Nelson, S. G.; Ambrose, B.; Martinez, R.; Soliz, D.; Pabendinskas, V.; Hultine, K. Comparison of salinity tolerance of three Atriplex spp. in well-watered and drying soils. Environmental and Experimental Botany, v.83, p.62-72, 2012. http://dx.doi.org/10.1016/j.envexpbot.2012.04.010

Hassine, A. B.; Lutts, S. Differential responses of saltbush Atriplex halimus L. exposed to salinity and water stress in relation to senescing hormones abscisic acid and ethylene. Journal of Plant Physiology, v.167, p.1448-1456, 2010. http://dx.doi.org/10.1016/j. jplph.2010.05.017

Hussin, S.; Geissler, N.; Koyro, H. W. Effect of $\mathrm{NaCl}$ salinity on Atriplex nummularia (L.) with special emphasis on carbon and nitrogen metabolism. Acta Physiologiae Plantarum, v.35, p.1025-1038, 2013. http://dx.doi.org/10.1007/s11738-012-1141-5

Kachout, S. S.; Mansoura, A. B.; Jaffel, K.; Leclerc, J. C.; Rejeb, M. N.; Ouerghi, Z. The effect of salinity on the growth of the halophyte Atriplex hortensis (chenopodiaceae). Applied Ecology and Environmental Research, v.74, p.319-332, 2009. http://dx.doi. org/10.15666/aeer/0704_319332

Khedr, A. H. A.; Serag, M. S.; Nemat-Alla, M. M.; El-Naga, A. Z. A.; Nada, R. M.; Quick, W. P.; Abogadallah, G. M. Growth stimulation and inhibition by salt in relation to $\mathrm{Na}^{+}$manipulating genes in xerohalophyte Atriplex halimus L. Acta Physiologiae Plantarum, v.33, p.1769-784, 2011. http://dx.doi.org/10.1007/s11738-011-0714-z

Malavolta, E.; Vitti, G.; Oliveira, S. A. Avaliação do estado nutricional das plantas: princípios e aplicações. 1.ed. Piracicaba: POTAFOS, 1989. 219p.

Matinzadeh, Z.; Breckle, S. W.; Mirmassoumi, M.; Akhani, H. Ionic relationships in some halophytic Iranian Chenopodiaceae and their rhizospheres. Plant Soil, v.372, p.523-539, 2013. http://dx.doi. org/10.1007/s11104-013-1744-7

Nedjimi, B. Effects of salinity on growth, membrane permeability and root hydraulic conductivity in three saltbush species. Biochemical Systematics and Ecology, v.52, p.4-13, 2014. http:// dx.doi.org/10.1016/j.bse.2013.10.007

Norman, H. C.; Wilmot, M. G.; Thomas, D. T.; Barrett-Lennard, E. G.; Masters, D. G. Sheep production, plant growth and nutritive value of a saltbush-based pasture system subject to rotational grazing or setstocking. Small Ruminant Research, v.91, p.103-109, 2010. http://dx.doi.org/10.1016/j.smallrumres.2009.11.022

Richards, L. A. Diagnosis and improvement of saline and alkali soils. Washington: US Department of Agriculture. USDA Agricultural Handbook, 1.ed. v.60, 1954. 160p.

Silva, E. C.; Nogueira, R. J. M. C.; Araújo, F. P.; Meloc, N. F.; Azevedo Neto, A. D. Physiological responses to salt stress in young umbu plants. Environmental and Experimental Botany, v.63, p.147-157, 2008. http://dx.doi.org/10.1016/j. envexpbot.2007.11.010

Silveira, J. A. G.; Araújo, S. A. M.; Lima, J. P. M. S.; Viégas, R. A. Roots and leaves contrasting osmotic adjustment mechanisms in responses to $\mathrm{NaCl}-$ Salinity in Atriplex nummuaria. Environmental and Experimental Botany, v.66, p.1-8, 2009. http://dx.doi. org/10.1016/j.envexpbot.2008.12.015

Souza, E. R.; Freire, M. B. G. dos S.; Nascimento, C. W. A.; Montenegro, A. A. A.; Freire, F. J.; Melo, H. F. Fitoextração de sais pela Atriplex nummularia Lindl. sob estresse hídrico em solo salino sódico. Revista Brasileira de Engenharia Agrícola e Ambiental, v.15, p.477483, 2011. http://dx.doi.org/10.1590/S1415-43662011000500007 
Souza, E. R.; Freire, M. B. G. S.; Cunha, K. P. V.; Nascimento, C. W. A.; Ruiz, H. U.; Lins, C. M. T. Biomass, anatomical changes and osmotic potential in Atriplex nummularia Lindl. cultivated in sodic saline soil under water stress. Environmental and Experimental Botany, v.82, p.20-27, 2012a. http://dx.doi. org/10.1016/j.envexpbot.2012.03.007

Souza, E. R.; Freire, M. B. G. S.; Melo, D. V. M.; Montenegro, A. A. A. Management of Atriplex nummularia Lindl. in a salt affected soil in a Semi Arid Region of Brazil. International Journal of Phytoremediation, v.16, p.73-85, 2014. http://dx.doi.org/10.108 $0 / 15226514.2012 .759529$
Souza, M. S.; Alves, S. S. V.; Dombroski, J. L. D.; Freitas, J. D. B.; Aroucha, E. M. M. Comparação de métodos de mensuração de área foliar para a cultura da melancia. Pesquisa Agropecuária Tropical, v.42, p.241-245, 2012b. http://dx.doi.org/10.1590/S198340632012000200016

Thomas, G. W. Exchangeable cations. In: Page, A. L. 2.ed. Methods of soil analysis. Part-2 chemical methods. Madison: American Society of Agronomy, 1982. p.159-165.

Walker, D. J.; Lutts, S.; García, M. S.; Correal, E. Atriplex halimus L.: Its biology and uses. Journal of Arid Environments, v.100, p.111-121, 2014. http://dx.doi.org/10.1016/j.jaridenv.2013.09.004 